\title{
PRKD1 Gene
}

National Cancer Institute

\section{Source}

National Cancer Institute. PRKD1 Gene. NCI Thesaurus. Code C95256.

This gene plays a role in protein phosphorylation and second messenger signaling. 